\title{
Counter-Insurgency in the Cape Colony, 1872 - 1882
}

\author{
J.S. Kotze $e^{\bullet}$
}

\begin{abstract}
The acceptance of responsible government in 1872 entailed that the Cape Colony had to provide its own security arrangements. The two British regiments that were still deployed at the Cape were reserved solely for imperial purposes. Moreover, the Cape Government now had to assist the High Commissioner with the maintenance of law and order in the adjacent tribal territories of the Transkei and Basotholand.

Unrest and internal conflict were almost endemic in the Cape Colony's area of interest during the period 1872 to 1882 . Besides a number of conflict situations of a smaller nature, the colonial forces were involved in five major insurgencies, namely the Cape-Xhosa or Ninth Eastern Frontier War (1877-1878), The Northern Frontier War (1878-1879), the Baphuhti Rebellion (1879), the Transkeian Rebellion (1880-1881) and the Rebellion in Basotholand (1880-1882).

This paper traces the development of policy and doctrine, administrative and military, by the Cape Government to pacify the Eastern Cape frontier region. Special attention is given to security and defence policy, the policy of direct control of the adjacent tribal territories as well as the disarmament policy. Furthermore the reactions of the indigenous communities to these policies as well as the demands placed on the colonial military system are investigated.

It is concluded that the policies of the successive Cape governments were either impracticable or resulted in the erosion of the traditional power structures among the black communities to the extent that from 1877 onwards, internal conflict became the order of the day. Perceived to be "mere instruments of political will", the colonial forces were synonymous with the reprehensible colonial control and found it impossible to deter public violence or prevent the escalation of the conflicts. The colonial government expected unrealistic strategic results from the colonial armed forces. Military reforms were mostly reactive and too little was done too late. The Molteno as well as the Sprigg ministry eventually paid the highest political price for the failure of their respective defence schemes not least of which was the failure of their counterinsurgency strategies.
\end{abstract}

\section{Introduction}

Thomas Mockaites observes that counter-insurgency, is but one of "... a constantly changing and imprecise array of terms..." which have been advanced over the years to describe essentially the same phenomenon, Others include "small wars", imperial policing", "counter-revolutionary warfare", "low intensity conflict", and, lately, "military operations other than war". ${ }^{1}$ Mockaites further states that counter-insurgency is basically about "...denying insurgents their

Centre for Military Studies, Faculty of Military Science, University of Stellenbosch.

Thomas R. Mockaitis, 'From Counterinsurgency to Peace Enforcement: New Names for Old Games', Small Wars and Insurgencies 10(2) 1999, p.40. 
objective..."2 which is ultimately "...to overthrow a nation from within using a combination of subversion, guerrilla warfare and terrorism."3 However, Mockaites argues that governments that attempt to deny insurgents their objective by reactive strategies will never be able to combat the insurgency successfully. Successful counter-insurgency first and foremost requires proactive measures by government to identify and address the insurgents' legitimate grievances. Furthermore military operations must be characterised by "minimum force", that is the highly selective and very discriminate use of force. ${ }^{4}$

Military theorists of the $19^{\text {th }}$ Century, such as Colonel C.E. Callwell ${ }^{5}$, the originator of the term "small wars", had a totally different conception of counter-insurgency. The use of military force was of the essence for campaigns of this nature and very little, if any, notice was taken of insurgents' grievances. Likewise, the predisposing and precipitating conditions ${ }^{6}$ resulting in internal conflict received scant attention. In fact, the whole etiology of internal conflict was seen in a different light with the causes of the insurgencies invariably attributed to the actions of "guerrillas", "banditti", "half-civilised races" or "wholly savage tribes". Callwell in this manner distinguished three classes of small wars according to their origins and causes, namely "campaigns of conquest or annexation", "campaigns for the subjugation of insurrections, revolts and rebellions, for the repression of lawlessness, or for the pacification of territories conquered or annexed", and "campaigns to wipe out an insult, to avenge a wrong, or to overthrow a dangerous enemy."7 The counter-insurgency campaigns conducted by the Cape Colony during the period under discussion, Callwell placed in the second category. ${ }^{8}$ The objective of a campaign of this nature according to Callwell was "... not only to prove to the opposing force unmistakably which is the stronger, but also to inflict punishment to those who have taken up arms." "9 The latter, apart from the defeat of the insurgent force, also required the destruction of property. However, Callwell was mindful of the fact that the political purpose behind such campaigns was to ensure a lasting peace and therefor destruction had to be limited to that which was absolutely necessary. As Callwell describes it: "...in choosing the objective, the overawing and not the exasperation of the enemy is the end to keep in view."10

The aim of this paper is to determine the Cape Colony's strategic approach toward counterinsurgency as is evident from the courses of action introduced in the eastern frontier region from 1872 to 1882 to cope with internal conflict in that region. The term eastern frontier region as used here, denotes the districts and tribal territories on either side of the Kei River, the Cape Colony's eastern border at the time, that is the former British Kaffraria, later Ciskei, and Transkei. Basotholand (later Lesotho) is excluded for the purposes of this paper and the rebellions that occurred there during the period under review, are only addressed in so far as it

Mockaitis, p. 41.

Mockaitis, p. 40; Steven Metz, 'The Future of Insurgency', Part 1, December 1993, http://carlislewww.army.mil/usassi/ssipubs/pubs93e/irsurg/insurgp1.html, 12/12/97, p.1, defines insurgency as '.. The use of low-level, protracted violence to overthrow a political system or force some sort of fundamental change in the political and economic status quo.'

Mockaitis, p. 41.

C.E. Callwell, Small Wars. Their Principles and Practice, $3^{\text {rd }}$ Ed. London, 1906.

For a discussions of these conditions, see Scott McNall and Martha Huggins, 'Guerrilla Warfare: Predisposing and Precipitating Factors' in Sam C. Sarkesian, Revolutionary Guerrilla Warfare, Chicago, 1973, pp. 241-254.

Callwell, pp. 25-28.

Callwell, p. 27.

Callwell, p. 41.

Callwell, p. 42. 
precipitated conflict in the eastern frontier region or gave rise to important political developments which affected that region.

The discussion of the relevant historical events starts with an overview of the Molteno ministry's perception of the security situation in the eastern frontier region upon the acceptance of responsible government in 1872 as opposed to that of its constituents living in or in close proximity to the region. Next, government's attempts to pacify the eastern frontier region from 1872 onwards through the extension of direct administrative and judicial control over the tribal territories of the Transkei, are addressed. Following that, the attempts made by the Molteno government to develop a suitable defence system to cope with the deteriorating security situation, which culminated in internal war in 1877 , are outlined. Thereupon the use of military force and other forms of retribution by the successive ministries during the Ninth Frontier War to bring the insurgents to submission, are reviewed. Further, the military and administrative reforms introduced by the Sprigg government in the wake of the Ninth Frontier War and the effects thereof on insurgency in the region, are considered. Subsequently, the impact of the successive rebellions in Basotholand on the Transkeian Rebellion (1880-81), and in particular the way in which the latter was brought to a conclusion, is described. Lastly, the military reforms introduced at the conclusion of seven years of intermittent conflict, are summarised. The paper ends with a number of conclusions drawn in terms of three strategic dimensions, i.e. political, military and social.

\section{The perceived security situation in the eastern frontier region}

By 1872 the Cape Colony's area of interest had been increased considerably due to the annexation of Griqualand-West and Basotholand to the Cape Colony in the previous year. ${ }^{11}$ The black tribal territories of the Transkei were not yet formally annexed and as such remained under the jurisdiction of the High Commissioner. However, the Cape government was obliged in terms of British colonial policy to assist the High Commissioner in all matters connected with the management of native affairs beyond the borders and was thus nominally responsible for the Transkeian territories as well. ${ }^{12}$

The acceptance of responsible government by the Cape Parliament in 1872 ipso facto entailed the obligation to develop the colonial defence system to the extent required to guarantee the security of the colony's area of interest without the assistance of the imperial government. ${ }^{13}$ In fact, prior to 1872 the Cape Parliament had refused more than once to accept responsible government because of the British government's drive since 1850 to curb defence spending by withdrawing the imperial regiments from the self-governing colonies. It was only after a compromise was reached with the War Office that two regiments were to remain at the Cape for a reasonable period, albeit on the express condition that the regiments were to be used for imperial purposes only and that the Colony establish a force for the maintenance of internal order

G.M. Theal, History of South Africa, Vol 9, London, 1915-1920 (Facsimile reprint by C. Struik, 1964), p. 69.

C.C. Saunders, 'The Annexation of the Transkei' in C. Saunders and R. Derricourt (eds), Beyond the Cape Frontier, London, 1974), p. 187.

13 R.C. Macleod, The Military and Police Organization of the Cape Colony, 1854-1881, Unpublished M.A. thesis, Queens University, Canada, 1967, p. 54. 
and security, that the Constitution Amendment Act, 1872, introducing responsible government at the Cape, was passed by the Cape Parliament. ${ }^{14}$

The way in which the Cape Government approached the issue of internal security and defence was closely related to its perception of potential threats to the safety and security of the Colony. ${ }^{15}$ Due to their historical experience of eight frontier wars, whites in general saw only one potential threat to the safety and security of the Cape Colony, namely the black tribes living within and adjacent to Colony, and in particular the Xhosa tribes of the eastern frontier region. However, there was a profound difference of opinion between whites of the Eastern Province and those of the Western Province regarding the prospect of war with the Xhosa. The same difference of opinion naturally occurred among parliamentarians representing the two provinces with the result that government's threat perception was concomitant with the composition of the ministry in terms of province represented.

Members from the Western Province generally believed that the power of the Xhosa tribes had deteriorated drastically as a result of the events of $1857^{16}$ and that the relocation of many clans from 1858 to 1865 had divided the tribes to such an extent that any unrest that might break out, would be so limited in nature that a well organised police force would be able to control it. ${ }^{17}$ Moreover, they argued that the Cape Colony had 21 years of peace and that the chances of another full-scale frontier war were diminishing rapidly. The Cape Colony was experiencing unprecedented economic prosperity and the black people were increasingly sharing in it. ${ }^{18}$ The diamond mines and railway construction and other public works created many job opportunities. As a result black people enjoyed a higher standard of living and was better educated than before. ${ }^{19}$ Against this background, Saul Solomon, the member for Cape Town, declared optimistically in the Legislative Assembly in 1873, that "no one in Parliament" saw any possibility of war. ${ }^{20}$ The Prime Minister, John Charles Molteno, represented Beaufort West, “... a Midland constituency with Western sympathies..." ${ }^{21}$ His threat perception was typically that of the Western Province. He personally handled the portfolio of defence and naturally exerted great influence on security and defence policy. ${ }^{22}$

Whites from the Eastern Province and in particular those living in or in the proximity of the potential conflict zone, were much more concerned about the security situation. They were particularly anxious about the disparity in numbers between whites and blacks in the eastern frontier region. ${ }^{23}$ Furthermore, they were inclined to perceive the large numbers of black people as "a sea of barbarism" which will abruptly engulf them. ${ }^{24}$ Some were convinced that unrest will break out any day because of the "chronic discontent and that constant feeling of rebellion"

14 P. Lewsen, 'The First Crisis in Responsible Government in the Cape Colony' (Archives Year Book for South African History, 1942, Part 2), pp. 215-216.

J.S. Kotze, 'Die Kaapse Staande Mag, 1872-1882’ (Archives Year Bookfor South African History, 1993), p. 13. The so-called National Suicide Movement of the Xhosa, or the great cattle killing of 1857.

Macleod, pp. 45-46.

CCP 3/2/4, Cape Parliament Debates, p.1, 24 April 1873 (Governor's Speech).

CCP 1/3/1/1, House of Assembly Debates, p. 76, 4 June 1874 (Colonial Secretary).

CCP 3/2/4, House of Assembly Debates, p. 30, 8 May 1873.

M.A.S. Grundlingh, 'The Parliament of the Cape of Good Hope, with Special Reference to Party Politics, $1872-$ 1910', Archives Year Book for South African History, 1969, Part 2, p. 149.

Macleod, p. 54.

CCP 3/2/4, House of Assembly Debates, p. 29, 8 May 1873.

CCP 1/3/1/1, House of Assembly Debates, p. 75, 25 June 1873. 
which was continuously at work in the "native mind". ${ }^{25}$ Others feared that the tribesmen "... might be seized with a sudden madness to break out into war..." 26 It was generally accepted that once war had broken out, even between the Xhosa tribes east of the Kei, it will inevitably spread to all the eastern frontier districts. ${ }^{27}$ Constant preparedness was the watchword and in this regard John Gordon Sprigg, the member of the Legislative Assembly for East London said: "If this immense mass of barbarism on our frontier sees that we are weak, that we are making no provision for the danger that threaten us ... we shall have perpetual outbreaks and constant alarms and the white inhabitants will always be subject to the apprehension of danger ..."28

An exception to the rule was Charles Brownlee, the Secretary of Native Affairs. Brownlee, who was previously a native commissioner in King William's Town, grew up with the Xhosa and knew their ways. He did not feel threatened by black people and believed that whites were unnecessarily concerned about conflict. ${ }^{29}$ However, in September 1872 war broke out between the Thembu and the Gcaleka of the Transkei. During a visit to the Transkei to facilitate a peace treaty between the warring tribes, Brownlee concluded that a control mechanism was necessary to ensure the peace and stability of the frontier region. He advised the Prime Minister to gain direct administrative and judicial control of all the tribes who wanted to avail themselves of the protection of the Cape Colony against their stronger neighbours. ${ }^{30}$ Government accepted Brownlee's advice and during the opening of Parliament on 24 April 1873 announced its policy to ensure the security of the frontier districts through the extension of the influence and authority of the Cape Colony amongst the tribes east of the Kei River to the Natal border. This was to be achieved by the appointment of resident magistrates with those tribes who wanted British rule. In addition the colonial mounted police force, the Frontier Armed and Mounted Police (FAMP), would be redeployed west of the Kei to be able to deal efficiently with any contingency that might occur anywhere in the eastern frontier region. ${ }^{31}$

\section{The establishment of direct control in the Transkei}

The first area beyond the Kei River to be administered directly by the Cape Colony was the Gatberg region of Nomansland (later Griqualand East) occupied by a number of smaller tribes that were already regarded as British subjects. Mfenguland, the Idutywa Reserve and the rest of Nomansland followed this in $1874 .{ }^{32}$ In 1875 fear of reprisal by the Gcaleka persuaded the Thembu to request the protection of the Cape Colony. This was granted by the Cape Government on the condition that the Thembu chief, Ngangelizwe, who was regarded as the real instigator of their conflict with the Gcaleka, would not be recognised as paramount chief. ${ }^{33}$ In the 1876 session the Cape Parliament resolved to strengthen its control over Thembuland through the division of the territory in judicial districts and the appointment of a chief magistrate and three magistrates. At the same time a resolution to annex Thembuland was despatched to Britain. In

CCP 1/3/1/1, House of Assembly Debates, p. 75, 25 June 1873.

The Cape Argus, 24 June 1873 (Parliamentary Debates).

Saunders, 'The Annexation of the Transkei', p. 187.

CCP 1/3/1/1, House of Assembly Debates, p. 75, 25 June 1873.

Macleod, p. 54.

NA 840, Native Affairs Department, Letters Despatched, Confidential, Annexure to Brownlee - Molteno, Cape Town, 2 May 1873.

CCP 3/2/4, Cape Parliament Debates, p. 1, 24 April 1873.

Kotze, pp. 16-18.

Theal, Vol 10, p. 47. 
the same year the chief magistracy of Griqualand East was created with its seat at Kokstad. A permanent resident-magistrate was also appointed for Gcalekaland. ${ }^{34}$

The decision to use the FAMP as a reaction force destined to be deployed in conflict situations in the Transkei, meant that counter-insurgency as opposed to general police work, such as the combating of stock theft, now became their first priority. It also entailed that the FAMP was to be withdrawn from all over the midland and frontier districts and concentrated in the major towns at or near the frontier to be able to move quickly to the trouble spots. Drill and musketry training was improved and at the same time an artillery troop was established. Soon the FAMP began to resemble an army unit. ${ }^{35}$

The Molteno government used the FAMP during the extension of direct control over the Transkeiean territories to create an image of strong military support for the administrative structures that were being created. The newly appointed resident-magistrates were invariably provided with strong-armed escorts to accompany and install them in their new positions. ${ }^{36}$ Furthermore FAMP detachments were permanently stationed at the residences. Whenever a situation arose that was beyond the ability of such a detachment to handle, reinforcements were quickly despatched from the Colony to demonstrate that "...Government was determined to be obeyed." ${ }^{\prime 37}$ At the same time the government showed its resolve and preparedness to combat insurgency, even in neighbouring colonies. In 1873 a contingent of 205 FAMP was sent to Natal as reinforcements during the Langalibelele Rebellion. A further 132 men were concentrated at Komgha to act as a reserve for the Langalibelele operation and to deal with any unrest that might break out in the Transkei in sympathy with the Langalibelele Rebellion. ${ }^{38}$

During the flaring-up of hostilities between the Gcaleka, the Thembu and the Mfengu in 1875-76 the FAMP conducted an extensive march of nearly seven months through Mfenguland, Gcalekaland and Thembuland to demonstrate government's support for the Mfengu and deter further violence. For this purpose almost the whole unit was dispatched to the Transkei under the personal command of the officer commanding, Commandant J.H. Bowker. As part of the show of force operation, Bowker, who acted as government representative, en route visited the chiefs for talks and, no doubt, to display government's military might. Finally Bowker convened a general meeting of the Thembu at Clarkebury, ostensibly to inform them about their incorporation with the Cape Colony. ${ }^{39}$

The parliamentary opposition generally approved government's extension of direct control over the tribal territories of the Transkei. However, the increasing use of the FAMP for general military duties was severely criticised by them, notably by J.G. Sprigg. Like many farmers of the Eastern Province, he was concerned over the fact that the FAMP no longer patrolled the frontier districts regularly and that as a result stock theft, and gun and liquour smuggling was rapidly on the increase. To them stock theft was a sure indicator of negative attitudes among

Theal, Vol. 10, pp. 47-48.

CCP $1 / 2 / 2 / 1 / 21$, A6-74, Report on the FAMP, 1874. Minutes of Evidence, p. 2;B. Williams, History of the Cape Mounted Riflemen, London, 1909, p. 16.

36 For example see CO 1020, Letters and Papers Received from FAMP, No. 96, Enclosure: Chalmers- Bowker, 28 May 1876.

37 CO 1020, No.96 Enclosure: Chalmers-Bowker, 28 May 1876.

38 CCP $1 / 2 / 1 / 26$, G 38-74, Report on the FAMP for 1873, p.2; CO 990, Letters Received, No. 27, Enclosure: Monthly Return and Distribution of the Frontier Armed and Mounted Police for November 1873.

39

CCP1/2/1/30, G 57-76, Report on the FAMP for 1875 , pp. 2, 4-7. 
blacks and was in fact regarded as "...a sort of undeclared warfare against whites." ${ }^{40}$ The Kaffrarian Farmers Association openly criticised Bowker's show of force in Thembuland and accused the FAMP of intimidating the Thembu to accept British allegiance. ${ }^{41}$

\section{Deterioration of the security situation in the eastern frontier zone and the Colonial Defence Commission of 1876}

Although colonial officials were of the opinion that the extension of direct control over Thembuland had had a "salutary effect" on the Thembu, ${ }^{42}$ magisterial governance to the detriment of chiefly authority achieved the opposite. In fact, the dismissal of Ngangelizwe as paramount chief was contrary to the traditional beliefs of the Thembu and injured a cornerstone of traditional African society. For the Thembu it was a matter of remaining loyal to the paramount under all circumstances in order to ward off evil. Soon even those who earlier had criticised Ngangelizwe's actions, clamoured for his reinstatement. Many tribesmen took it for granted that Ngangelizwe will resort to arms to regain his honour. In due course reports were circulated that the Thembu were preparing for war. As these reports reached the Colony "... rumours of an alarming nature were put into circulation ...". 43

Direct control also met with resistance in Griqualand East. Neither the Griqua nor the Basotho clans were prepared to accept full colonial control over their affairs. Moreover they were disturbed by the appointment as Chief Magistrate of Captain Matthew Blyth who had the reputation of an extremely autocratic official. Several incidents of unrest occurred and although Blyth eventually succeeded in quashing the resistance, it was mostly due to the ability of the FAMP to provide relatively high force levels in the area. ${ }^{44}$

Towards winter of 1876 a "war scare" gripped the frontier districts. This was fuelled to no end by newspaper reports that black people in the past few years have acquired some 200000 firearms through smugglers on the diamond fields and public works in the Cape Colony. Reports of a conspiracy between the Thembu and Gcaleka chiefs against the Colony had a similar effect. Just at this time news of the South African Republic's unsuccessful campaign in Sekhukhuneland and of impending war in Zululand, reached the frontier districts. Rumours even had it that Cetswayo's messengers were seen all over the Transkei and Basotholand. Farmers associations repeatedly voiced their concern over the general feeling of insecurity among the farming communities. In June 1876 the member for King William's Town mooted the farmers' fear of a united front between the various Black tribes against the whites in Parliament. ${ }^{45}$

Sprigg, supported by the Eastern province parliamentarians, again urged Molteno to appoint a colonial defence commission to revamp the colonial defence system. Given the deteriorating security situation, Molteno had no option but to comply. This was an important victory for the "easteners" and in particular for Sprigg, who was also appointed chairman of the commission. ${ }^{46}$

\footnotetext{
40 M.W. Spicer, The War of Ngayecibi, 1877-78 (Unpublished MA thesis, Rhodes University, 1978), p. 26.

41 W.B. Campbell, 'The South African Frontier, 1805-1885: A Study in Expansion' (Archives Year Book for South African History, 1959, part 1), p. 137.

C2 CP 4/1/1/3, G 39-76, Report by Special Commissioner for Transkeian Affairs, 1876, p. 21.

43 CCP 1/2/1/32, G 12-77, Blue Book on Native Affairs for 1877, p. 172.

44 Kotze, p. 30.

45 Campbell, p. 138.

46 CCP 1/2/1/32, G 1-77, Report on Colonial Defence, 1877, Warrant, 7 August 1876.
} 
The Colonial Defence Commission wasted no time and before the end of October 1876 a report was submitted to government. A typical Eastern Province threat perception emanates from the report. Moreover it is evident that the "war scare" of 1876 took a heavy toll on the Commission's objectivity. All the black people of the eastern frontier region, in and beyond the borders of the Cape Colony, were counted as potential enemies. Not even the Mfengu, who had a long history of loyalty to the Cape Colony and who were destined to support the colonial forces once again in the Cape-Xhosa War, was regarded as friendly. The Commission was blind to everything but the notion of a black conspiracy resulting in a joint invasion of the Colony, despite the conspicuous impracticability of such a scheme. As concerns the probability of war, the Commission was convinced that dissatisfaction and unrest have increased to such an extent among black people, especially the Thembu that "the Colony is living as upon a mine, that at any moment may be sprung beneath its feet." 47

The force design proposed by the Commission was conventional by nature. It provided for two lines of defence with the FAMP as the colonial permanent force, forming the first line of defence and the citizen force and volunteer units, the second. For this purpose the FAMP had to be enlarged to 1500 men, 400 of whom were to be deployed in advanced posts in the proximity of the most threatening tribes, whereas the rest would man the existing police stations and devote themselves to patrol duties. To assume responsibility for colonial defence and command the colonial forces on the frontier, a career officer had to be appointed as Commander of the Colonial Forces. Furthermore, suitable fortifications had to be erected to protect the major frontier towns as well as the railway and telegraph lines. Police stations also had to be fortified. ${ }^{48}$

Commandant Bowker, who halfway through the sittings had withdrawn from the work of the Commission, distanced himself from the findings. He articulated his views in a letter to Molteno that was published as a sort of minority report. Bowker argued that the Commission had completely misjudged the security situation on account of the "war scare". The latter he attributed to efforts of "sundry political and intriguing missionaries", "misguided politicians", "scare-bitten officials" and the imperial troops. He assured Molteno that there was no chance of a conspiracy between the black tribes. ${ }^{49}$

In Parliament Sprigg made much of the efforts of the Colonial Defence Commission "to provide at the least cost and inconvenience to the inhabitants of the colony, a living active force in the sight of the people against whom the force is provided. ${ }^{, 50}$ However, government was not easily convinced that the situation warranted such drastic measures. Molteno knew that Sprigg was often given to alarmist ideas and prefer the sober advice of Brownlee, and even Bowker. Moreover, Brownlee have visited the tribes personally in the last quarter of 1876 and found no evidence of alliances or hostile designs against the Colony. Brownlee have established that the root of the evil as far as the Thembu was concerned, was the degradation of Ngangelizwe and since that was rectified with his reinstatement in November $1876^{51}$, the disturbances in Thembuland have ceased. Any remaining negative attitudes among the blacks, Molteno believed, was offset by the advantages they stood to gain from the socio-economic developments in the Colony. John X. Merriman, a prominent member of the Molteno ministry, declared that

\footnotetext{
CCP $1 / 2 / 1 / 32$, G $1-77$, p. 6.

CCP $1 / 2 / 1 / 32$, G $1-77$, pp. 7-8.

CCP 1/2/1/32, G 1-77, Appendix, pp. 1xviii-1xix.

CCP 1/3/1/2, House of Assembly Debates, p. 39, 25 June 1877.

CCP 1/2/132, G 12-77, p. 179.
} 
the danger of a frontier war was eliminated by the increase in "wealth and civilization". 52 When the issue was put to the vote in the House of Assembly, a motion by Sprigg to the effect that the recommendations of the Defence Commission be accepted, was turned down by 32 votes to $25^{53}$

\section{The Ninth Frontier War, 1877-78}

The appointment of the resident-magistrate for Gcalekaland in the person of Colonel J.T. Eustace, a retired British officer, in November 1876 gave rise to a new set of rumours. News of Col. Eustace's appointment coincided with that of the disembarkation of imperial troops in East London. The grapevine now had it that the real purpose of all this was to invade Gcalekaland and kill the paramount chief, Sarhili. When Col. Eustace arrived in late November with the usual FAMP escort to be introduced to Sarhili, it was said to be the advance guard of the invasion. Sarhili quickly took off and when he later appeared, he confessed that a strong war party has taken root among his people and that he was finding it increasingly difficult to keep the peace. ${ }^{54}$

The main reason for the growing discontent of the Gcaleka, apart from the erosion of chiefly authority through the imposition of colonial rule in Gcalekaland, evidently was the land issue, and in particular, the generalised belief that they were deprived of their land to the advantage of the Mfengu and the Thembu. Since the relocations of 1864, the Gcaleka lived in the southwestern portion of their former territory, i.e. the districts of Willowvale (Gatyana) and Kentani (Centane). ${ }^{55}$ This state of affairs left them with very little room for manoeuvre. Sarhili later remarked that the Gcaleka felt hemmed in between the sea and Mfenguland and saw no option but to fight to regain the south of Mfenguland as well as the Idutywa Reserve. Although Sarhili was concerned that such a course of action would result in war with the Colony, he was hoping that the FAMP would stay out of the fight like during the Thembu-Gcaleka War of 1872 and that after a few battles colonial officials would intervene and arrange a settlement that was more favourable for the Gcaleka. ${ }^{56}$

However, the incident that set in motion the chain of events, which ultimately resulted in the Ninth Frontier War, was the killing of a Gcaleka tribesman and simultaneous assault on two Gcaleka headmen who attended a wedding feast at the kraal of Ngcayecibi in Mfenguland on 3 August 1877. In an attempt to redress the wrongs, the head of the Gcaleka clan to which the men belonged, a few days later raided a number of kraals in the vicinity of Ngcayecibi's and captured several hundred cattle. Officials from the residences succeeded in defusing the situation by persuading the Gcaleka to return most of the cattle and the Mfengu not to retaliate. Nevertheless small skirmishes and looting between the Gcaleka and the Mfengu continued. ${ }^{57}$

On 19 August 1877 the Chief Magistrate of Mfenguland, James Ayliff, informed government that a well-known Mfengu chief, Bikitsha, had received word that the Gcaleka was planning to

\footnotetext{
P. Lewsen, John X. Merriman: Paradoxical South African Statesman, Johannesburg, 1982, p. 63.

CCP 1/3/1/2, House of Assembly Debates, p. 39, 25 June 1877.

Spicer, pp. 55, 57.

J.S. Bergh and J.C. Visagie, The Eastern Cape Frontier Zone, 1660-1980, Durban, 1985, p. 56.

P.Gon, The Road to Isandlwana, Johannesburg,1979, p. 102; OPB 1/23, C 1961, Further Correspondence Respecting the Affairs of South Africa, p. 106, No. 43, Annexure: Undated statement by West Fynn; C.J. Schoeman, 'Die Negende Grensoorlog, 1877-1878' (Unpublished MA thesis, University of Port Elizabeth), p. 85.

57 OPB 1/23, C 1961, pp. 68-69: Memorandum by C. Brownlee, 28 August 1877; Spicer, p. 68; Theal, Vol. 10, pp $54-55$.
} 
attack his kraals near Butterworth. A contingent FAMP under command of Inspector E.B. Chalmers, was immediately sent to Butterworth to protect the Mfengu, but also to keep them in check. $^{58}$ The expected raid on Bikitsha's took place during the night of 24/25 August 1877 despite attempts by Calmers and the other officials to persuade groups of Gcaleka assembling for the action not to join in. The raid, led by Sarhili's son, Sigcawu, turned out disastrously for the Gcaleka who lost 24 men against seven Mfengu. However, the heavy casualties made the Gcaleka more determined than ever to defeat the Mfengu. The next day the Gcaleka warriors were called to assemble at Sarhili's kraal for the war rituals. When confronted about the turn of events, Sarhili denied that he was in favour of war, but admitted that it was becoming impossible to control his people who were obsessed with the casualties suffered against the Mfengu. ${ }^{59}$

The governor, sir Bartle Frere, together with ministers Merriman and Brownlee at this stage visited the Transkei. Brownlee, who knew Sarhili well, went to see him in person. Sarhili avoided Brownlee altogether. It now became evident that Sarhili was increasingly intimidated by a number of hotheads within his inner circle of councillors and family members. They wanted him to take a firm stand and "....act with what they held to be the dignity of an independent chief, and not go like a hound because a white man called him." As a result Sarhili avoided all contact with the colonial government, which might force him to make concessions that he will ultimately be unable to put to practice. ${ }^{60}$

After assessing the situation at first hand Governor Frere redeployed the available forces and reallocated responsibilities. The only imperial battalion in the region, $1 / 24^{\text {th }}$ Regiment of Foot, was deployed west of the Kei to guard against a Gcaleka invasion. The FAMP was deployed in point defence at Ibeka near Butterworth as well as on its line of communication between King William's Town. An advanced post at Idutywa was also manned by the FAMP. The commander of this sub-unit, inspector Chalmers, at the same time replaced the magistrate there. Commandant Bowker, whose health was failing, was replaced by Commandant C.D. Griffith, who until then, was Governor's Agent in Basotholand. The Chief Magistrate of Mfenguland was instructed to organise and command a Mgengu levy to assist the colonial forces. Finally Col. Eustace and his staff were withdrawn from Gcalekaland. With that all formal liaison with the Gcaleka was severed. A few days earlier, on 21 September 1877, Sarhili had told a visitor: "I mean war with the English as well as the Fingoes ${ }^{, 61}$.

By 25 September 1877 several Gcaleka incursions into Mfengu territory had taken place. Merriman, who was acting as an informal "Minister of War", instructed the FAMP to shoot at the Gcaleka if they ventured into Mfenguland again. ${ }^{62}$ The next day a Gcaleka impi raided Mfengu kraals in the vicinity of Mount Gwadana. The FAMP under Chalmers, together with Ayliff's Mfengu irregulars, intervened but due to bad battle-handling was routed by the Gcaleka. An officer and six men of the FAMP were killed. ${ }^{63}$

The Battle of Gwadana was a turning point. The Gcaleka was greatly encouraged by its outcome and was determined to continue with their war plans. The governor and colonial

\footnotetext{
58 Spicer, pp.74-75; An Ex C.M.R. (pseud. For A.K. Granville), With the Cape Mounted Rifles, London, 1881, pp. $51,65$.

59 Spicer, pp. $78,80,82$.

60 Theal, Vol. 10, p. 58.

61 Quoted by Spicer, p.100.

62 GGR 1, Letters Received, Unnumbered, Telegram Merriman - Chalmers, 25 September 1877.

63 Kotze, pp. 46-47.
} 
ministers requested reinforcements from Cape Town and invited volunteers to join. Officials and other civilians were evacuated from Mfenguland and the Idutywa Reserve. The defences at Ibika were strenghtened and all available forces concentrated there, including some $2000 \mathrm{Mfengu}$. On 29 September 1877 the Gcaleka army of between 7000 and 8000 men attacked the field fortifications at Ibika in traditional close order formation and was decisively defeated with casualties amounting to a 1000 men dead or wounded. ${ }^{64}$

With the spectre of full-scale war looming, Governor Frere centralised the command of the colonial forces under the general officer commanding the imperial forces in South Africa, Lieutenant General Arthur Cunynghame. ${ }^{65}$ Together with Merriman, Brownlee, and Cunynghame, Frere formed an Executive Council at King William's Town to coordinate the conduct of the war. A renewed call was made for volunteers and at the same time a Thembu levy was raised by the Chief Magistrate of Thembuland, Major H.G. Elliot. Griffith, now local rank Colonel, was given command of the Transkei Field Force and was ordered to conduct offensive operations in Gcalekaland to effect the surrender of the Gcaleka. The Transkei Field Force consisted at the outset of the campaign of 1022 mounted officers and men as well as 4000 Mfengu and 2300 Thembu irregulars. ${ }^{66}$ On 5 October 1877 a proclamation was issued, stipulating that Sarhili was forthwith deprived of his chieftainship and that the tribal territory was expropriated in totality and was to be occupied by the Transkei Field Force. ${ }^{67}$

Griffith started the offensive in Gcalekaland with the destruction of Sarhili's kraal at Holela as well as that of other members of the Gcaleka leadership. ${ }^{68}$ Thereafter several mounted columns scoured Gcalekaland and systematically burnt or destroyed all huts and food supplies, while thousands of cattle were taken as loot and used as slaughter-animals or sold off. ${ }^{69}$ The columns encountered very little resistance from the Gcaleka and it was thought at first that they were completely demoralised. By December 1877 patrols started to make contact with substantial numbers of Gcaleka warriors and several running battles ensued. Griffith then realised that all the while the Gcaleka was evacuating their young women and children and as many cattle as they could, to safety in Mpondoland and elsewhere and that the warriors were returning to join battle again - an old Xhosa tactic ${ }^{70}$ Soon after it was established that Sarhili was hiding with a large force near the coast. Frere thought that the "neglected defensive forces of the Colony" was by then so run down that they would not be able to cope with the exigencies of the campaign and instructed Cunynghame to organise an imperial task force to proceed with the operations against the Gcaleka. ${ }^{71}$

Molteno was furious because the operational command in the Transkei had been given to the imperial commanders. All along he was critical of Frere's interference and maintained that the "war" was nothing but a police action and as such was a colonial affair. He refused to admit that the colonial defence system was failing and together with Merriman heaped all the blame on Colonel Griffith, who as Merriman said, “.... in the very hour of our victory ... had made such a

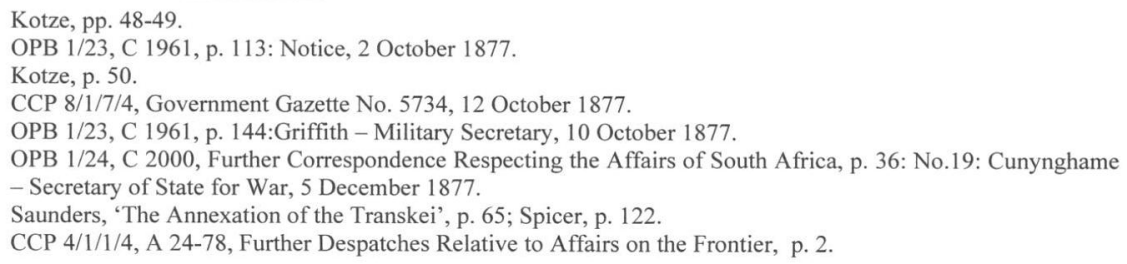


serious and overwhelming blunder... ${ }^{72}$ Frere stood his ground and repeatedly accentuated the weaknesses in the Cape's security arrangements. He was particularly critical of the FAMP and declared outright: " ...for the moment, the Frontier Armed and Mounted Police have collapsed and lost the confidence of their fellow-citizens."73

By December 1877 indications of unrest among the Ngqika became all too obvious. Animosity between the Ngqika and the colonial Mfengu surfaced. The Ngqika accused the Mfengu of collaboration with the Colony against the Xhosa. Their participation in the campaign against the Gcaleka in particular was unpardonable. The Ngqika paramount chief, Sandile, hesitated for a long time to come out in open support for the Gcaleka, but by the end of the year he declared that he could no longer sit still while Sarhile fights. ${ }^{74}$ On 28 December 1877 several Mfengu kraals were raided and some farmhouses, shops and a hotel near Komgha set alight. ${ }^{75}$ On 30 December 1877 the first important battle of the war west of the Kei River took place at Draaibosch near Komgha. ${ }^{76}$ The Ngqika Rebellion was now an accomplished fact. On 31 December 1877 martial law was proclaimed in the districts of Komgha and Stutterheim. At the same time the governor urgently requested reinforcements from the War Office. ${ }^{77}$ On 3 January 1878 the Burgher Act was published which enabled government to call out the burgher commando's. ${ }^{78}$

The imperial campaign in the Transkei commenced on 26 Decemember 1877. The operational commander, Colonel R.T. Glyn, basically followed the same operational plan as Col. Griffith. Resistance again was slight at first and was overcome without breaking the advance. Once Ngqika warriors had infiltrated across the Kei River resistance stiffened. On 13 January 1878 Glyn's right column had to deploy for a deliberate attack to dislodge a combined GcalekaNgqika force from its position at Nyumaga. ${ }^{79}$ Soon after information pointed to a concentration of Gcaleka and Ngqika warriors in the Mnyameni bush and it was decided to establish a fortified base at Kwa-Centane. Early on 7 February 1878 a joint Gcaleka-Ngqika force of 5000 of their best warriors tried to surprise the defenders but failed to do so and was defeated with losses of up to 400 men. ${ }^{80}$ The Battle of Centane proved to be the decisive battle of the war against the Gcaleka. It destroyed their morale and brought an end to organised resistance in Gcalekaland. ${ }^{81}$

In the meantime the differences between Governor Frere and the Molteno ministry came to a head over the conduct of the campaign against the Ngqika. Molteno thought that the rebellion would best be suppressed by colonial forces under the command of colonists "...not encumbered by military impedimenta..." and insisted on an independent colonial campaign west of the Kei River. ${ }^{82}$ The idea of a dual command structure in the same area of operations was inconceivable to Frere and he refused to approve. Molteno nevertheless went ahead with his plans and

J.C. Molteno Collection, No. 758: Merriman-Molteno, 15 December 1877.

CCP 4/1/1/4, A 24-78, p. 4: Telegram, Frere-Molteno, 19 December 1877.

Spicer, p. 143.

OPB 1/24, C 2000, p. 129.

OPB $1 / 24$, C 2000 , pp. $115 ; 144-146$

OPB 1/24, C 2000, p. 112-113.

Lewsen, John X. Merriman: Paradoxical South African Statesman, p. 69.

See Kotze, pp. 77-78.

See Kotze,pp. 79-84.

Spicer, p. 170.

CCP $1 / 2 / 1 / 38$, A 2-78, Correspondence, etc relating to the dismissal of the late Ministry, p. 30: Memorandum by J.C. Molteno, 2 February 1878. 
informed Frere that the colonial forces were to be separated from the imperial troops and placed under the command of the newly appointed Commandant General of Colonial Forces, Colonel C.D. Griffith, who in turn would serve "...under the sole control and direction of the Colonial Government." ${ }^{83}$ On 31 January 1878 a new row broke out between Frere and Molteno when the latter refused to sign the treasury documents accepting the expenses on behalf of the Colony pertaining to the reinforcements requested by the governor and who were already on their way from Britain. Frere realised that the feud between himself and Molteno will inevitably result in the political demise of one or them and informed the Molteno ministry that they will be dismissed as soon as their successors have been identified, whereupon they all resigned. ${ }^{84}$ Frere's actions were subsequently ratified by the Cape Parliament and by the British government. In fact, it was said at the time that the dismissal of the Molteno ministry was the most popular thing which Sir Bartle Frere had done since his arrival in the Cape Colony. ${ }^{85}$

\section{Sprigg's military and administrative reforms}

Governor Frere appointed J.G. Sprigg as Prime Minister. Like Frere, Sprigg blamed the Western Province dominated Molteno ministry for the failures of the colonial defence system. Consequently Sprigg appointed mostly parliamentarians from the Eastern Province as ministers and devoted his tenure to military reforms and the reorganisation of administration of the tribal territories. $^{86}$

Sprigg's first order of business was the conclusion of the Ngqika Rebellion for which purpose he deemed it necessary to postpone the 1878 session of parliament. However, after the Battle of Centane, Sandile and the other Ngqika chiefs have withdrawn to the Amatola Mountains and proved it to be an excellent base for guerrilla operations. ${ }^{87}$ Despite their initial successes, in the long run the Ngqika were unable to withstand the pressure exerted by the imperial and colonial forces, now acting in unison. After a number of the Ngqika leaders had been killed or captured, resistance crumbled. By May 1878 Sandile started to throw out feelers for negotiations. Sprigg was determined to subjugate the Ngqika once and for all and insisted that Sandile surrendered unconditionally. His followers obstinately refused to give in until their leaders have received amnesty. Consequently the rebellion continued until Sandile himself was fatally wounded on 28 May $1878 .{ }^{88}$ Finally on 29 June 1878 government announced an amnesty for the ordinary tribesmen who were willing to present themselves to the authorities for that purpose. Those in positions of leadership were excluded from the amnesty offer and had to surrender formally. ${ }^{89}$

83 CCP 1/2/38, A 2-78, p. 17:Memorandum by J.C. Molteno, 22 January 1878.

84 P. Lewsen, 'The First Crisis in Responsible Government in the Cape Colony' (Archives Year Book for South African History, 1942, part 2), p. 249.

85 Grundlingh, p. 174.

86 Kotze, p. 91.

87 Spicer, p. 181.

88 Kotze, p. 96.

89 DD 1/6, Papers Received from Colonial Military Secretary and Colonial Secretary, No. 294: Telegram SpriggGriffith, 12 July 1878 . 
Parliament met in May 1878 amid distressing news of unrest and rebellion throughout South Africa. In the same month the Second Korana War broke out along the Orange River. ${ }^{90}$ The idea of a "black conspiracy" was again propagated by many contemporary observers including Sir Bartle Frere who saw in it "...a wish among the great chiefs to make this war a general and simultaneous rising of Kaffirdom (sic) against white civilization."'11 Sprigg's calls for an efficient system of colonial defence this time fell on responsive ears, especially in view of the Colonial Office's recent warning that the Colony will not in future be able to rely on the assistance of the imperial forces. ${ }^{92}$ The Sprigg government tabled no less than five bills for "...the defence of the colony and the preservation of the peace among the native tribes...", all of which were passed without much debate. ${ }^{93}$

The corner stone of Sprigg's defence system was the Peace Preservation Act, informally known as the Disarmament Act. ${ }^{94}$ It provided for the proclamation of affected districts in which the ownership of unlicensed weapons would be prohibited, as well as for the handing-in of such arms and ammunition for compensation. The maximum penalty for the illegal possession of firearms was fixed at 500 pounds sterling or seven years imprisonment. In terms of the act, licenses for arms and ammunition would be issued to "fit and proper persons" only. It was generally accepted among whites that a black man was not "fit and proper" in this sense, because "...the possession of a gun makes him believe that he is the white man's equal in strength and tend to make him unruly." ${ }^{\prime 5}$ Furthermore it was widely believed that the danger of a black rebellion will be all but eliminated if blacks were not allowed to possess firearms. Sprigg's disarmament policy was enthusiastically supported by Governor Frere who professed to have personal experience of the benefits of disarmament in India. ${ }^{96}$ The Act was at first proclaimed only in the frontier districts, Mfenguland and Emigrant-Thembuland. By February 188010860 rifles and 15764 assegais were handed in for compensation in the amount of 31076 pounds sterling. These results convinced Frere that disarmament was "...by no means an abortive or inoperative measure, nor one the enforcement of which is dangerous to the public peace..." However, subsequent events were to prove that tribesmen did not part easily with their weapons and that it was only those who were completely loyal to government, like the Mfengu, who did so. ${ }^{98}$

The creation of a colonial defence force with the ability to adjust its force levels according to necessity was likewise a prime objective for the Sprigg government. For this purpose a permanent force to be augmented in "times of trial and danger" by a series of part-time units

M.Broodryk, 'Die Rebellie in Griekwaland-Wes, 1876-1879' (Unpublished MA thesis, University of South Africa), p. 8.

J. Martineau, The Life and Correspondence of Sir Bartle Frere, Vol. 2, London, 1895, p.223.

GH 4/6, Confidential Despatches, No. 9, pp. 53-54: Carnarvon-Frere, 24 January 1878.

Martineau, p. 220.

94 Act 13-1878, An Act for the better Preservation of Peace within the Colony, Statutes of the Cape of Good Hope 1874-1878, pp. 374-380; The contemporary historian George McCall Theal (Vol. 10, p. 117) mockingly referred to the act as "(an act) for the promotion of discontent and war within the colony". Theal, Vol. 11, p. 55.

96 PMO 3, Minutes Received from Governor and High Commissioner, No. 893: Minute for Ministers by H.B.E. Frere, 2 February 1880.

97 PMO 5, Minutes Received from Governor and High Commissioner, No. 73: Frere - Secretary of State, 17 March 1880.

98 C. Brownlee, pp. 206-207; Theal, Vol. 11, p. 56. 
In September 1879 Griqualand East, the Idutywa Reserve and Mfenguland was officially annexed to the Cape Colony. At the conclusion of the Baphuthi Rebellion the CMR resumed its occupation of these territories. Due to continual unrest in Griqualand East and its proximity to Basotholand, half of he regiment was stationed there. The rest reoccupied its former positions in Thembuland and Mfenguland. ${ }^{114}$

\section{The Basotho rebellion and the rebellion in the Transkei}

The Baphuthi Rebellion, if anything, made J.G. Sprigg more determined than ever to continue with the disarmament policy. Contrary to the advice of many of his contemporaries, but again wholeheartedly supported by Sir Bartle Frere, Sprigg proclaimed the Disarmament Act in Basotholand on 6 April 1880. A Basotho delegation hoping to convince government to "let disarmament sleep", reached Cape Town just in time to see a motion against the proclamation defeated in the House of Assembly. ${ }^{115}$ The majority of those voting against the motion represented eastern constituencies. The "easteners" point of view was that any concessions made under pressure will be regarded by blacks as a sign of weakness and will only encourage them to continue to challenge the authority of the white man. ${ }^{116}$ Sprigg naturally interpreted the results of the division as a vote of confidence and was only prepared to postpone the return date for the handing in of weapons in Basotholand to 21 July $1880 .{ }^{117}$

By the end of July 1880 anarchy reigned supreme in Basotholand. Hoping that the presence of a strong military force will deter the Basotho and enable him to reach a settlement with the Basotho chiefs, Sprigg ordered the CMR to send a task force to Basotholand. ${ }^{118}$ However, Sprigg underestimated the Basotho's resolve and when he later visited Basotholand, he found himself unable to negotiate any agreement with the chiefs without abandoning disarmament. Sprigg now decided that the Basotho were "rebellious in their hearts" and would not stop short of complete independence from the Cape Colony. ${ }^{119} \mathrm{He}$ ordered the CMR to occupy Maseru and Mafeteng to protect the officials and the loyal Basotho who sought refuge there.

En route to Mafeteng on 13 September 1880 the CMR column joined issue with a Basotho force but managed to reach its objective intact. On 17 September 1880 a CMR detachment was attacked by some 700 Basotho near Mafeteng. Sprigg, who had called at Mafeteng the previous day, watched the superior force massed against the CMR and concluded that the only way to end the rebellion was to mobilise the colonial forces and coerce the Basotho into submission. However, this time the Colony would have to do without the support of the imperial forces. Due to a change of government in Britain, Sir Bartle Frere was recalled and the acting governor, the general officer commanding the imperial forces, Major General Henry Clifford, entirely disapproved of Sprigg's policies. As a result he advised the British government that "whatever

114 CCP 4/2/1, G 56 - 80, Report of the Commandant-General, 1879, pp. 29-30.

115 Grundlingh, p. 193.

116 Vanstone, p. 67.

117 CCP 1/3/1/4, House of Assembly Debates, p. 102, 15 June 1880.

118 Macleod, p. 129.

119 Martineau, Vol. 2, p. 382.

120 DD 6/2, Orders, Telegram Clarke - Carrington, 2 September 1880; DD 1/273, Basuto War Papers, Telegram Clarke-AAG, 2 September 1880. 
dimensions this outbreak may assume ... no Imperial Troops may be allowed to take part in it." ${ }^{121}$ The War Office welcomed this and no deviation from the rule was allowed. ${ }^{122}$

News of the Basotho rebellion quickly spread to the adjoining districts of Herschel, BarklyEast and Griqualand East. Soon reports of incitement and intimidation from Basotholand reached the magistrates, while stock theft increased hand over hand. ${ }^{123}$ From Griqualand East, Charles Brownlee reported that the Basotho clans south of the Drakensberg have received calls to join the rebellion as a result of which his area of responsibility was thrown "into the utmost excitement". ${ }^{124}$ Brownlee at first attempted to persuade the Basotho leadership to remain loyal to the Colony, but then received word from Matatiele about a plan to kill him and the other officials, whereupon he ordered all whites to leave the district and assemble in Kokstad. The rebels then turned their vengeance upon the loyal tribes such as the Hlubi and Bhaca. ${ }^{125}$

The next district in Griqualand East to be affected was Maclear. As the Transkei by then was almost denuded of colonial forces, magistrate Hamilton Hope of Qumbu arranged with the Mpondomise chief, Mhlontlo, to provide troops to the magistrate of Maclear, On 23 October 1880 Hope, accompanied by three officials, had just delivered a wagonload of arms and ammunition to Mhlontlo for this purpose when they were surprised and killed. ${ }^{126}$ The other notable Mpondomise chief, Mditshwa, also rebelled and held the magistrate of Tsolo together with a few white families and black constables hostage in the town goal. Numerous incidents of looting and arson occurred in Thembuland and scores of refugees started to arrive in Umtata. ${ }^{127}$ The Chief Magistrate at Butterworth tried to organise a strong Mfengu force but found the onetime loyal folk reluctant to join because they have already surrendered their weapons in terms of the Disarmament Act. ${ }^{128}$ Moreover they were now being victimised by the rebels and had to muster all their strength for self-protection. ${ }^{129}$

The news of the dramatic events in the Transkei, in the words of Theal, "...burst upon the colonial government and people like a sudden thunderclap."130 The rebellion was all over interpreted as the outcome of a conspiracy between the tribes to throw off white rule fomented from Basotholand. ${ }^{131}$ That the Basotho Rebellion indeed was the precipitating event and that incitement from that quarter took place is not in doubt. Furthermore, the rebels south of the Drakensberg did avail themselves of the opportunity to start the rebellion when the colonial forces were fixed in Basotholand. However, these aspects are merely some of the links in a complex causal chain. Rebel-leaders who were later questioned said that the rebellion occurred because the people feared that disarmament would be extended to the rest of the Transkei. ${ }^{132}$ Others blamed the introduction of direct colonial rule and in particular the usurpation of

121 GH 23/37,General Despatches, No. 4, p. 160: Clifford - Kimberley, 20 September 1880.

122 For an account of the Basotho Rebellion, see Kotze, Chapters. 6 and 7.

123 CO 1110, Letters Received, Telegram CC Herchel - Clarke, 28 September 1880

124 C Brownlee, Reminiscences of Kaffir Life and History, Lovedale, 1896, p. 210.

25 CCP 1/2/1/45, G 20-81, Blue Book on Native Affairs, pp. 73-74: Report by C Brownlee, 12 October 1880

126 C.C. Saunders, 'The Transkeian Rebellion of 1880-81: A Case Study of Transkeian Resistance to White

Control', South African Historical Journal, No. 8, November 1976, p 36.

127 CCP $1 / 2 / 1 / 45$, G 20-81, pp. 22-24: Report by H.G. Elliot, 1 January 1881

128 CCP 1/2/1/45, G 20-81, p.40: Report by M. Blyth, 7 January 1881.

129 Saunders, 'The Transkeian Rebellion of $1880-81$ ', p. 37.

130 Theal, Vol. 10, p.161.

131 CCP 1/2/1/45, G 20-81, p. 21; 69; CO 1142, Letters Received, No. 3/1108, Annexure, p. 57.

132 Saunders, 'The Transkeian Rebellion of $1880-81$ ', p. 34. 
authority over tribal affairs by the magistrates. ${ }^{133}$ The magistrates themselves thought that the colonial laws introduced in the Transkei such as the Pass Law, "...pressed somewhat heavily upon the natives..." and resulted in an indifferent attitude towards the Colony. ${ }^{134}$ The Xhosa of the Transkei was by nature very conservative and found the dislocation of traditional government and way of life that followed in the wake of colonial rule, intolerable. Furthermore agitators such as Mhontlo cleverly exploited the tensions between the people and the colonial administration. To the black people the white officials were the personification of government and it was widely believed that if an official was killed, government would "hurt'. Many naively believed that if the white officials could be liquidated colonial rule would disappear and the old order would be reintroduced. ${ }^{135}$ However, the violence was not restricted to officials or whites. Black people loyal to government, such as the Mfengu - called "kumsha" or black Englishmen - also became the victims of all sorts of atrocities. ${ }^{136}$

The turning point in the Rebellion in the Transkei came when the West-Mpondo chief. Nqwiliso, sent a force to Chief Magistrate Elliot for the relief of the Tsomo magistracy. More black troops joined the colonial forces and started to play a significant role in the repression of the rebellion. Prominent in this respect were the Bhaca, Hlubi and Mfengu contingents. The colonial government also succeeded in recruiting several temporary volunteer units, some from as far afield as Natal. ${ }^{137}$ The available forces were distributed among the three chief magistracies and subdivided into garrisons for the important towns as well as mobile columns. ${ }^{138}$ Early in November 1880 these mobile columns started with offensive operations. By now Ngangelizwe and most of the Thembu clans had come out in support of the government forces. Within a month the colonial forces started to gain the upper hand in Griqualand East and Thembuland. On 18 December 1880 the Mpondomise rebellion was brought to an abrupt end when Mhlontlo's impi was decisively defeated in the Battle of Tsitsa Gorge. Some 300 warriors were killed where upon the impi dispersed. ${ }^{139}$ Soon mounted patrols dominated the rebel districts. Since the offensive started, hundreds of rebels have been killed while large numbers have surrendered. Many have fled into the mountains ahead of the mounted patrols. The rebellious clans were no longer able to protect or hide their livestock and these were captured in thousands by the colonial forces. $^{140}$

In Basotholand the colonial forces have not made much headway since the outbreak of the rebellion. Completely outnumbered by the rebels, the colonial forces were restricted to three enclaves around Hlotse, Maseru and Mafeteng. Although they have managed to defend their positions successfully and have never been defeated in any of the many battles and skirmishes, the colonial forces could not regain the strategic initiative. As a result the morale of the forces deteriorated with a corresponding decline in offensive action. Eventually the Sprigg government

133 CCP 3/1/1/44, A 54-80, Petition of Emigrant Tembu Chiefs, p. 1.

134 CCP $1 / 2 / 1 / 45$, G 20-81, p. 39: report by M. Blyth, 7 January 1881.

135 Saunders, 'The Transkeian Rebellion of $1880-81$ ', pp. 35,37.

136 Saunders, 'The Transkeian Rebellion of $1880-81$ ', p. 37.

137 By 31 December 1880 the colonial forces in the Transkei numbered 9586 of all ranks of which only 2395 were white ( CO 5895, Government Notice No. 2/1881)

138 CCP 1/2/1/45, G 20-81, p.22, 25: Report by H.G. Elliot, I January 1881.

139 CO 1111, Letters Received, No. 2/1071, Annexure: Report by J.F. Baker, 21 december 1880.

140 CO 5895, Government Notice No 38/1881. 
had to abandon its aim of an unconditional surrender of the Basotho in favour of a negotiated settlement. This, however proved to be a long and tedious process. ${ }^{141}$

In Parliament the opposition made capital of the Sprigg government's inability to end the Basotho Rebellion. Opposition spokesmen like Thomas Scanlen and John X. Merriman, openly declared that Sprigg's defence system had collapsed and that all his military reforms were not worth the money spent on it. Narrowly defeating a motion of no confidence, the Sprigg government on 5 May 1881 tendered its resignation. ${ }^{142}$

Sprigg's successor, Thomas Scanlen, soon discovered that despite his more moderate approach, leading members of the Basotho leadership passionately refused to accept the settlement proposed by Governor Hercules Robinson. ${ }^{143}$ Hoping to remove the root of all evil, the Scanlen government on 5 May 1882 rescinded the proclamation of the Disarmament Act in Basotholand, but to no avail. ${ }^{144}$ In desperation Scanlen turned to Britain to take over the control of Basotholand. Direct imperial rule of Basotholand was introduced on 18 March $1884 .{ }^{145}$

\section{The military reforms of 1881-82}

Three factors compelled the Scanlen government to embrace a policy of retrocession towards Basotholand and the Transkei, namely the Colony's inability to bring the situation in Basotholand under control, the realisation that direct colonial control do not automatically ensure political stability and that the colonial treasury due to the prohibitive costs of the rebellions of 1879-1882 would not be able to carry the costs of continual conflict with the black people. ${ }^{146}$

Typical of someone with a conflict-avoiding management style, Scanlen did not give the same priority to military preparedness and the development of the colonial defence system as his predecessor. However, the insecurity of 1881 gave rise to two select committees on defence which both recommended considerable changes to the colonial forces. Moreover, in February 1882 the Scanlen government requested from Britain the services of the legendary Major General Charles Gordon. Major General Gordon was appointed Commandant General of the Colonial Forces and in his brief span of office of some seven months produced numerous reports on the colonial forces recommending sweeping changes. All of these reports were tabled during the 1882 session of Parliament, the result of which was that Parliament was faced with the task of "preparing for the last war"! Although not many of the recommendations were actually approved, those that were approved, amounted to significant changes. Firstly the permanent force was enlarged with the establishment of a regular infantry regiment, styled the Cape Infantry. The Cape Mounted Riflemen and the Cape Field Artillery were retained as independent regiments. These three permanent force units were deployed in Basotholand and the Transkei as garrison forces and as reaction forces. In addition to its military duties the CMR was responsible for preventative policing in the Transkei. The headquarters of the Colonial Forces remained in King William's Town. Secondly the Cape Mounted Yeomanry was disbanded whereas the other

141 Kotze, p. 229.

142 CCP 1/3/1/5, House of Assembly Debates, p.37, 8 April 1881, p.44, 11 April 1881; Grundlingh, p. 197.

143 DD 1/275, Basuto War Reports and Diaries, No. 613: Griffith - Clarke, 19 May 1881

144 Grundlingh, p. 200.

145 Theal, Vol. 11, p. 79.

146 Saunders, 'The Annexation of the Transkeian Territories', p. 110; Saunders, 'The Transkeian Rebellion of 1880-81', p. 39. 
part-time volunteer units were to be used within their districts only as before. In times of crises burghers and native levies could be called out to augment the permanent force. Thirdly, a rural police force, the Cape Police, was established to police the frontier districts west of the Kei River. Although black constables were appointed in the Cape Police, no blacks were taken up in any of the permanent force regiments. ${ }^{147}$

\section{Conclusions}

In the absence of political parties in the Cape Colony at the time, opposition politics in Parliament revolved around security and defence policy that in turn was based on one of two opposing perceptions of the Colony's security situation depending on whether the incumbent ministry was Western Province or Eastern Province oriented. The "easterners" favoured an aggressive stance as opposed to the 'westerners' who preferred a more moderate approach. The political fortunes of the successive governments depended almost exclusively on the success or failure of their security and defence policies. Native policy in either case proved to have been merely an adjunct of the former. The Molteno as well as the Sprigg ministry ultimately paid the highest political price as a direct result of the failure of their respective security and defence policies. The position the governor took in respect of security matters had a decisive impact on opposition politics, not only because of his influence in Parliament but also because of his intercession at the Colonial Office. Molteno's recalcitrance towards Governor Frere in this respect hastened his political demise whereas Frere's support for Sprigg's policies enabled it to run its course. As Frere's influence with the British government waned, Sprigg experienced more and more resistance from that quarter. When Frere left the Colony it was just a matter of time before Sprigg's tenure was cut short.

Both the Molteno and the Sprigg governments entertained the notion that political stability in the eastern frontier region could be achieved through the extension of direct control over the whole of the region. Sprigg in particular promoted the idea and apart from the outright annexation of some tribal territories, imposed a series of social control measures on the black people in that area. The latter found direct colonial control reprehensible and eventually black resistance again turned into insurgency. Ultimately, Scanlen realised the futility of these policies and turned towards a policy of retrocession from the tribal territories but not before the total strategic power base of the Colony was allowed to go to rack and ruin.

The primary role government envisaged for the colonial forces and the permanent force in particular, was the pacification of the eastern frontier region. In this respect the colonial forces had a dual purpose. Firstly it had to keep the peace for the officials to implement policy and, secondly, should internal conflict occur, it had to swiftly defeat the insurgents to enable the politicians to conclude a settlement on their terms. The force design preferred by the Molteno government consisted of two tiers, namely a full-time paramilitary force, that, in addition to police work in the frontier districts, could also serve as a reaction force inside and outside the Colony, and secondly, a part-time force to augment the permanent force if and when the need arise, consisting of volunteer units, burgher forces and native levies. The Frontier Armed and Mounted Police was quickly cast in the role of the permanent force and after 1873 was used more and more as a regular army unit beyond the Kei River on garrison, armed escort and deterrence missions. During the Ninth Frontier War the FAMP was used as a regular mounted

147 Kotze, pp. 260-262. 
infantry unit. Sprigg added another tier to the existing force design directly below the permanent force, namely the Cape Mounted Yeomanry. In addition Sprigg enlarged the permanent force establishment substantially. The militarisation of the FAMP continued under the Sprigg government and culminated in 1879 in its conversion into the Cape Mounted Riflemen. Although the CMR remained on the statute book as a military and police force, it was never used as a police force until 1882. Instead it was used to occupy strategic positions in the Transkei and serve as a reaction force, in which capacity it played a leading role during the rebellions in Basotholand. Moreover under the Sprigg government the colonial forces were progressively moulded into a conventional formation. An important result of this organisational drift was the establishment of a permanent Colonial Forces Headquarters. Independent full-time units of a specialised nature were also established, namely an artillery battery (CFA) and an infantry regiment (CI). By 1882 the Cape Colony had a small conventional army at its disposal for use in the adjacent tribal territories. However, the military reforms and reorganisations were mostly reactive due to misconceptions about the relative strengths of the opposing forces and the colonial forces' capabilities. The most obvious source of manpower, namely black troops were not utilised on a permanent basis, mainly because of government's reluctance to involve black people more closely in colonial defence.

In the Cape Colony little if any distinction was made between regular or conventional war and counter-insurgency. The successive Cape governments approached the use of military power in situations of internal conflict, as they would have in done any "small war". In fact, counterinsurgency in the Cape Colony closely resembles the description of "small wars" given by Callwell. As conventional strategies and tactics were used to combat insurgency, a coherent and sustainable counter-insurgency doctrine was never developed. The nearest the policymakers came to such a development, was during the Transkeian Rebellion when due to the fact that the military authorities were occupied in Basotholand, the planning, control and administration of operations against the insurgents were delegated to the three chief magistrates in their capacity as regional administrators.

Military power was used in the classical British land power or continental tradition, that is directly instead of indirectly, with the ultimate military strategic aim being the destruction of the insurgents' will to resist through the destruction of its armed forces, the occupation of its territory and the decapitation or neutralisation of its leadership structures. Military strategic concepts such as limited war or the use of minimum force in order to facilitate a political or negotiated settlement were evidently inconceivable to the incumbents. Sprigg for one insisted on the unconditional surrender of insurgents. Consequently attempts by the insurgents to start negotiations were shunned by government as ploys to gain time.

On the operational strategic level there was a marked preference for annihilation rather than attrition, hence the incessant search for the decisive battle. Because of that the colonial forces often started a campaign with an offensive-defensive strategy, establishing a field fortification or fire support base in or near insurgent territory to entice an insurgent attack. In the campaign against the Gcaleka in 1877 such a fortification was built in Mfengu territory at Ibeka and the subsequent attack on Ibeka resulted in the decisive defeat of the Gcaleka impi. The imperial forces later followed a similar operational strategy to finally defeat the combined GcalekaNqgika impi in the Battle of Centane. This time the field fortification was erected near the assembly area of the Gcaleka and Nqgika forces. Tactically firepower was of the essence in 
battles of this nature. However, these battles were by no means static. Mounted forces were regularly used to execute tactical manoeuvres or for exploitation or pursuit.

Although less popular, especially with colonial politicians because of time and cost involved, circumstances often dictated the use of operational strategies in which attrition was dominant. In operations of this nature several mounted columns assisted by black contingents would advance through insurgent territory to make contact with insurgent forces and through deliberate attack destroyed the insurgent forces sequentially. In this respect insurgent leaders were the prime targets. At the same time the mounted columns would capture the insurgents' livestock and systematically destroy insurgent property such as kraals, dwellings or crops thereby eliminating their ability to resist. In 1878 Nqgika resistance was finally broken with a strategy such as this. In 1881 the Transkeian Rebellion was ended in a similar fashion.

The Cape government showed a very limited understanding of the causes and the dynamics of insurgency. Notions that insurgents might have legitimate grievances, or that an insurgency might be a reaction against repressive governmental policies, or that unwillingness to introduce reforms to meet the insurgent's demands leaves government with military repression and retribution as the only way to stop the insurgency, were clearly foreign to governmental decision makers. In fact, in the Cape Colony insurgency was regarded as a military rather than a sociopolitical problem and a conventional military problem at that. The outcome of such a mindset was that the very social control measures adopted by government to inhibit conflict, such as magisterial governance, the depletion of chiefly authority, the relocation of tribes, or disarmament, created such immense frustrations and resistance in some quarters that ultimately not even certain retribution could deter rebellion. Likewise the purely military approach to counter-insurgency had the effect that the underlying political, social or economic causes of the insurgency were never identified nor addressed. The implication of this was that, as the root causes of the insurgency were not eradicated, the insurgency perpetuated itself and the Transkeian Rebellion followed the Ninth Frontier War. Another negative effect of the military approach was that insurgents were regarded as "the enemy" resulting in the progressive alienation between government and the population. However, what remains unanswered and requires further research is why so many Transkeian tribes remained loyal to government and even co-operated in the suppression of the Rebellion.

The successive governments were all at a loss to deal with news reports and rumours about black resistance against white control which, from 1875 onwards circulated in the eastern frontier region. What gave a special significance to this is that it coincided with a series of internal wars and rebellions throughout South Africa, which occurred more or less at the same time. The actual effect of these perceptions on the internal conflict in the eastern frontier region and the extent to which it prompted decision makers to overreact, still needs to be determined. Likewise the question whether the insurgents merely encouraged one another, or whether there indeed was some sort of a conspiracy between blacks to engage in a trial of strength with whites, requires further research. 